\title{
UAV を活用した海岸地形変化解析に関する研究
}

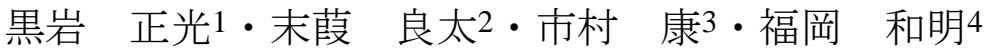 \\ 1正会員 鳥取大学大学院 工学研究科 教授（ \\ E-mail:kuroiwa@cv.tottori-u.ac.jp \\ 2学正会員 鳥取大学工学部土木工学科（=680-8552 鳥取県鳥取市湖山町南4-101） \\ E-mail: B12T6028Z@edu.tottori-u.ac.jp \\ 3正会員 日本ミクニヤ株式会社 執行役員（干556-0021大阪府大阪市浪速区幸町3-1-10） \\ E-mail:ichimura@mikuniya.co.jp \\ 4日本ミクニヤ株式会社 大阪支店 主任（†556-0021大阪府大阪市浪速区幸町3-1-10） \\ E-mail:fukuoka@mikuniya.co.jp
}

\begin{abstract}
本研究では, 浦富海岸の海岸侵食対策を検討するためのひとつの手法として, 砂浜域を比較的高頻度で, なおかつ簡易的にモニタリングできるシステムを開発することを目的としている．本報では，UAVにより 得られた空撮画像についてSfMを用い3次元モデルを作成し海岸地形変化の解析を行ったのでその結果に ついて報告する。

UAVは、4枚羽の飛行体を用い，2秒間隔の撮影で $80 \mathrm{~m}$ 上空を飛行させた，得られたデータは，SfM専用 ソフトとGISソフトを用い解析を行った。

UAVを用いた海岸線の調査は，約 $2 \mathrm{~km}$ 程度であれば，所用時間20分程度で済み，比較的簡易にモニタリ ングが行えることが確認できた.また,精度については、RTK-GPS測量結果との比較から0.05m程度である ことが確認できた.
\end{abstract}

Key Words : UAV, GIS, SfM, 3 -dimensional model, Coastal topography

\section{1. はじめに}

近年，急速に普及し始めた，無人小型ヘリコプター は，簡便に空中写真の撮影が行えるため，地形や構造物 の計測および測量1)，道路やインフラの点検等，様々な 分野で活用されるようになってきている. 普及に伴い, 各団体から安全飛行に関するガイドライン ${ }^{23)}$, 手引き4) および基準5も出されている。また，国土地理院から公 共測量のためのマニュアルのも出されている.

さらに, 複数の写真からカメラの撮影位置を推定する 技術や3次元形状を復元する技術も普及し始めて，簡便 に写真測量が行えるようになりつつある。このような背 景の中，3次元形状を復元するモデリングソフトウエア の精度検証 ${ }^{78)}$ ，さらには写真のオーバーラップ率やカメ ラのレンズ種類が与える影響などについても調べられて おり ${ }^{8)}$ ，高い精度が報告されている。

鳥取県東部の浦富海岸は，港と岩礁で囲まれたポケッ トビーチで，海岸侵食と航路堆砂が問題となっている. 対策として，航路での浚渫土砂を海上土砂投入するサン ドリサイクルが実施されている。しかしながら抜本的な 解決とはなっておらず新たな対策を検討する必要があり, 海浜変形と波浪との関係をモニタリングする必要がある.
本研究では，浦富海岸の海岸侵食対策を検討するため の一つの手法として，砂浜域を比較的高頻度で，なおか つ簡易的にモニタリングできるシステムを開発すること を目的としている。本報では，UAV(Unmanned Aerial Vehicle)により得られた空撮画像についてSfM(Structure from Motion) を用い3次元モデルを作成し海岸地形変化の 解析を行ったのでその結果について報告する.

\section{2. 空中写真撮影}

\section{(1) 調査対象場所}

調査は，図-1に示す鳥取県東部の東西約 $1.5 \mathrm{~km} の$ 岩美

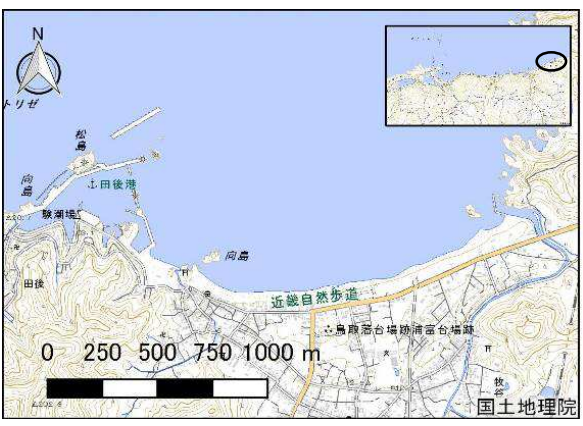

図-1 調査対象場所 
町浦富海岸で2015年11月29日，12月18日および2016年1月 13日にかけ行った。当該地周辺には、飛行に影響を与え る電波塔等の構造物はなく, 安全性は確認された場所で あった。

\section{(2) 撮影方法}

撮影に使用した機体は，写真- 1 に示す．機体は，井 上ら゙)を参考に筆者らが，DJ社製の組み立てキット F 450に，自動飛行のため3Drobotics社製のフライトコント ローラーAPM2.6を搭載し作成した4枚羽の飛行体であ る. 空中撮影は，カメラを下向きに搭載し，約 1600 万画 素，焦点距離 $18.3 \mathrm{~mm} の$ 民生カメラ(GR : リコー社製)を用 い，写真毎に6割以上オーバーラップするように2秒間隔 の撮影を，高度 $80 \mathrm{~m}$ から行った。 なお，撮影は調査対象 場所を東西の2区域に分け区域毎に行った。撮影時の機 体操作は，離陸までは手動で操作を行い，ある程度の高 度に達したのち，GPS を用いた自立飛行をさせた１回 の飛行時間は10分程度であった。

\section{(3) 標定点と検証点}

標定点は，3次元モデルに座標を与えるために必要で あり，区域毎に区域の東西および中心付近に，地形状態 に合わせて14から21点設定した．また，11月29日の調査 では，作成するモデルの精度検証のために用いる検証点

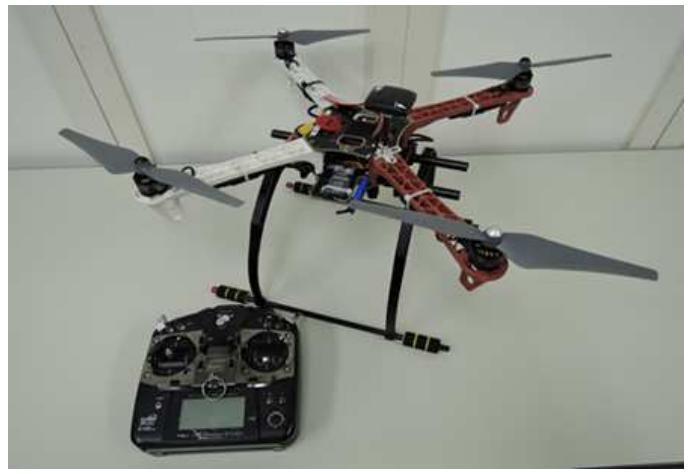

写真-1 マルチコプター

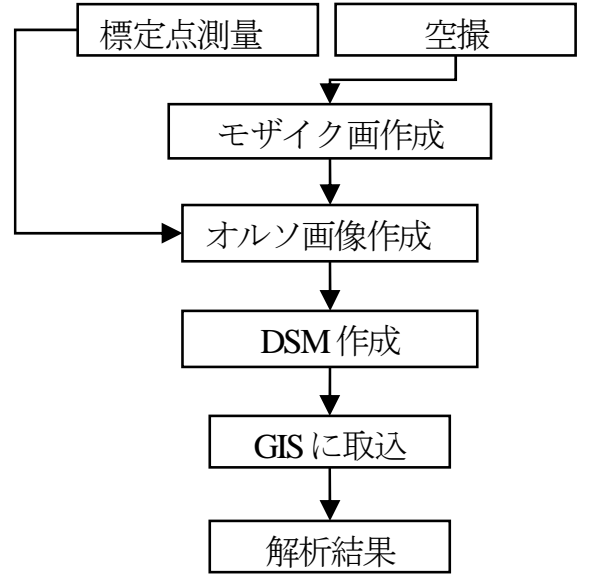

図-2３次元モデル作成と解析の流れ
を11点設置した．標定点および検証点の位置座標は， VRS方式のネットワーク型RTK-GPSにより求めた.

(4) 岸沖方向断面測量

UAVによる断面形状および高さの観測結果の精度を 確認するために，岸沖方向の断面地形の緯度，経度およ び標高をRTK-GPSを保持し，歩きながら2秒間隔で自動 観測した.

\section{3. 空中写真による 3 次元モデル作成}

空中撮影写真は，図-2に示す流れで処理を行った. 3 次元モデルの作成は, 複数の静止画からカメラの撮影位 置や3次元形状を推定するSfM技術，カメラパラメータ から高密度の点群を作成し3次元形状を復元する MVS(Multi-View Stereo) 技術を用いたソフト PhotoScanPro.(AgiSoft社製)で行った。図-3は，SfMによっ て出力されたカメラの位置および方向で, 青面がカメラ の位置，黒線が撮影方向をそれぞれ示す. PhotoScanPro では，計算時間を短縮させるためと精度を向上させるた めに，より詳細なモデルを作成できるHightモードにて 解析を行った。 その後，得られた 3 次元モデルの DSM(Digital Surface Model)は，フリーのGISソフトQGISに 取り込み解析を行った。

Hight乇ードの解析は，パソコンのスペックによるが,

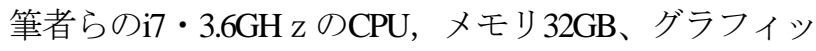
クボードGTX960のパソコンで約200枚の写真を解析する のに、10時間程度の計算時間を要した。

\section{4. 精度検証}

精度検証は，標定点と検証点の比較より行った. 図一 4は精度検証の結果を示す。困中に示す值は，RMSE值 (平均二乗誤差)であり，標定点についてはソフトから算 出される誤差から求め, 検証点についてはオルソ画像上

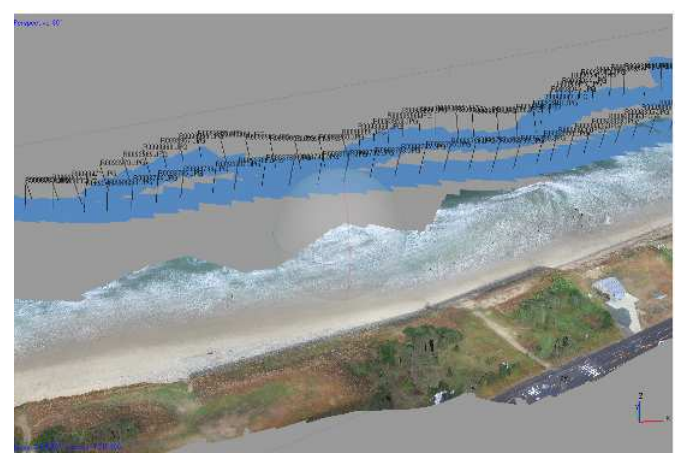

図-3 SfM出力結果 
で検証点を確認し，その場所の水平位置と高さを求め, RTK-GPSにより得られた值を真值として算出した. なお, 標定点は3回の調査の平均值で，検証点は11月調査時の 平均值である。

図-4によると標定点は，その位置と高さを用いてモデ ルを作成しているため，水平精度 $0.021 \mathrm{~m}$ ，高さ精度 $0.018 \mathrm{~m}$ となた。 しかし, 検証点の精度は, 水平精度 $0.053 \mathrm{~m}$ となり, 高さ精度 $0.029 \mathrm{~m}$ となり, 標定点の精度よ り悪い結果となった。これは，11月時の天候は雨時々量 りの状態で，雨の合間をめって飛行させたため天候の影 響で，空中撮影画像が良好でなかったことにより精度が 落ちたものと考えられる.

平成28年3月に出された「UAVを用いた公共測量マニ ユアル(案)」のには，計測誤差の制限は，標定点および検 証点ともに水平および高さ精度 $0.05 \mathrm{~m}$ 以内であることと されており，今回の調査では標定点は制限を満たしてい るが，検証点における高さ精度は満たしていない．しか しながら, 海岸地形変化をとらえるには十分な精度であ るといえる.

精度を向上させるためには，地上測量の精度を上げる こと，標定点の数を増やすこと，オーバーラップ率やサ イドラップ率を高めること等が必要である．また，標定

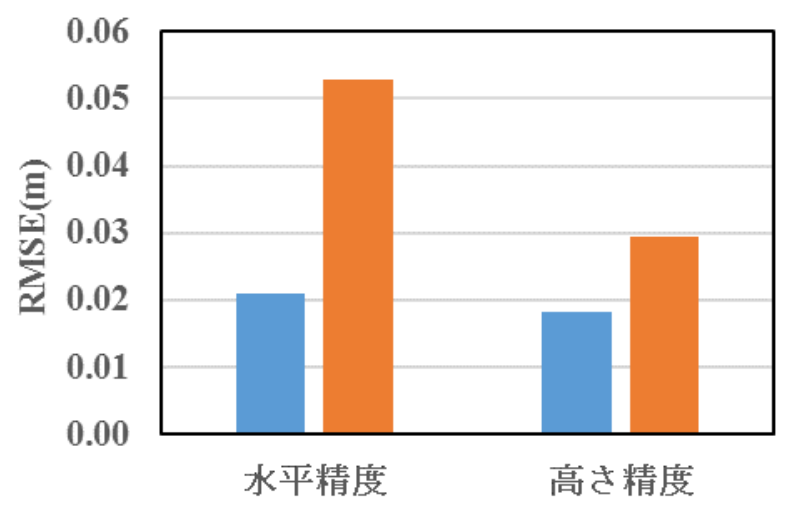

標定点 日検証点

図-4 水平精度と高さ精度
点については，対象とするエリア囲むように設置し，囲 んだエリア内にも点を設置する必要がある，さらに，設 置場所の周囲が開けた場所に設置する必要や，陰になら ないような場所に設置するなどしなければならない. な お，光を反射する水などや動いているものなどは，写真 合成の際のマッチングポイントが得られにくく，精度が 悪くなり，極端に地盤高が高くなったり低くなったり， 等高線が凸状態になったり，幾つもの小さな閉曲線の 塊ができたりする，そのため，波打ち際の解析には，図 -5に示すようなオルソ画像や必要に応じ個別に空中写真 で確認しながら進める必要がある。

\section{5. 海岸地形変化解析}

\section{(1) 断面形状}

図-6は，図-5中のラインについて、RTK-GPS測量から 得られた結果と，3次元モデルから得られた結果を断面 図として示したものである. RTK-GPSによって得られた 結果を青のラインで，3次元モデルより得られた結果を 赤点でそれぞれ示す.

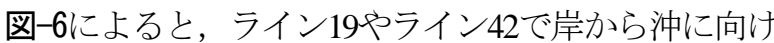
て変曲点を有する断面もRTK-GPS と3次元モデルから得 られた結果は，比較的良く一致しており，傾向を捉えて いる。しかしながら，12月のライン29では，RTK-GPSと 3次元モデルから得られた結果では，約1m近くの差が出 ている. ライン29はテトラポットを横切るようなライン となっており，測定点が開けた空間でないと近傍の高さ に引つ張られ地盤高が高くなるというソフトの特徵によ って出たものと考えられる.

図-7は，各ラインにおける断面地形の経月変化を示す。 図-7によると，ライン19では堆積傾向にある。 ライン 29では11月と12月は変化がなく，その後堆積している. ライン42では，汀線近傍で11から12月にかけ侵食し，そ

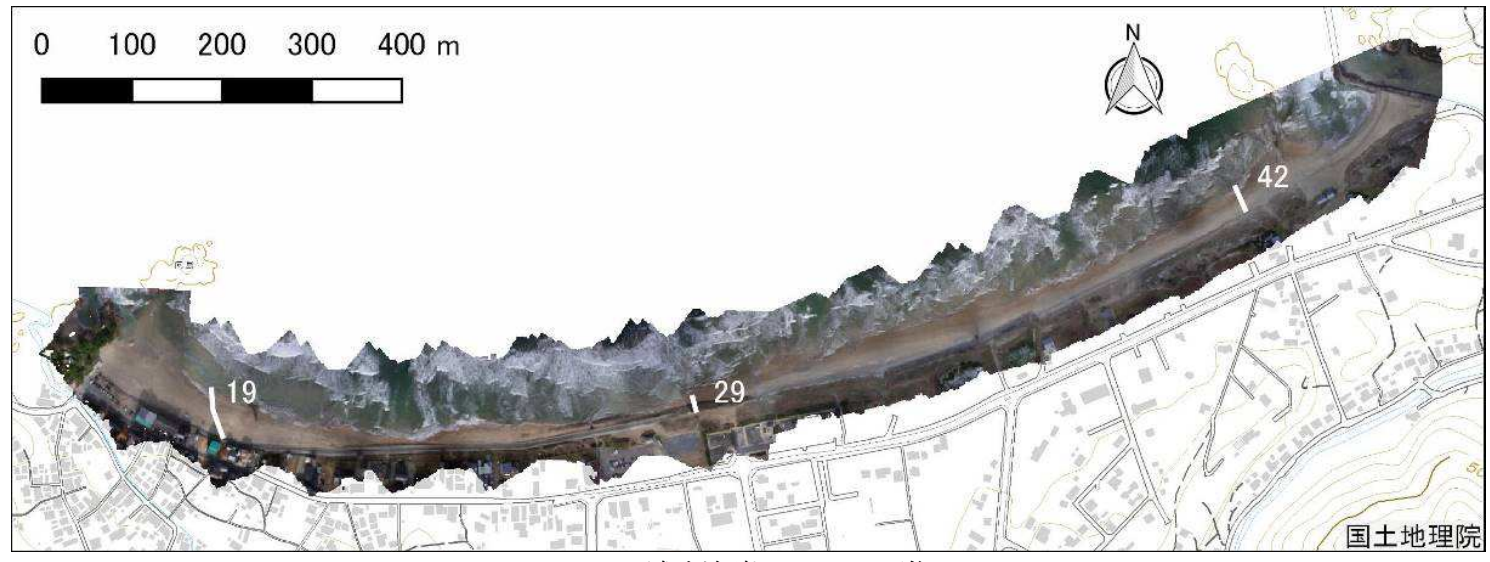

図-5＼cjkstart浦富海岸のオルソ画像

(図中のラインは岸沖方向断面測定箇所, 数值はライン番号) 
の後堆積している.

複雑な構造物がある場合は，精度に課題が残るが，短 時間で広範囲の地形測量が行えるUAVによる手法は効 果的である．さらに，3次元モデルを作ることが容易で， 面的に地形情報を取得することができ，任意の断面形状 を捉えることができる.

\section{(2) 汀線変化}

図-8は，DSMより求めたTP0.0 mのラインを汀線とし て，経月変化を示したものである．TP0.0 mの等高線は， 波打ち際に当たるために, 先にも記述したように, DSMから求めた等高線だけでは, 判別がつかないため, オルソ画像と等高線を照らし合わせて, 汀線を推測した.

汀線は，図中の測線1の東西，測線12から14，測線 16 から23でそれぞれ前進傾向がみられた。一方，測線6, 測線15で後退傾向がみられた。 なお，測線7から11にか けては変化がみられなかった．全体的に11月から1月に かけ東西で前進傾向にあった。
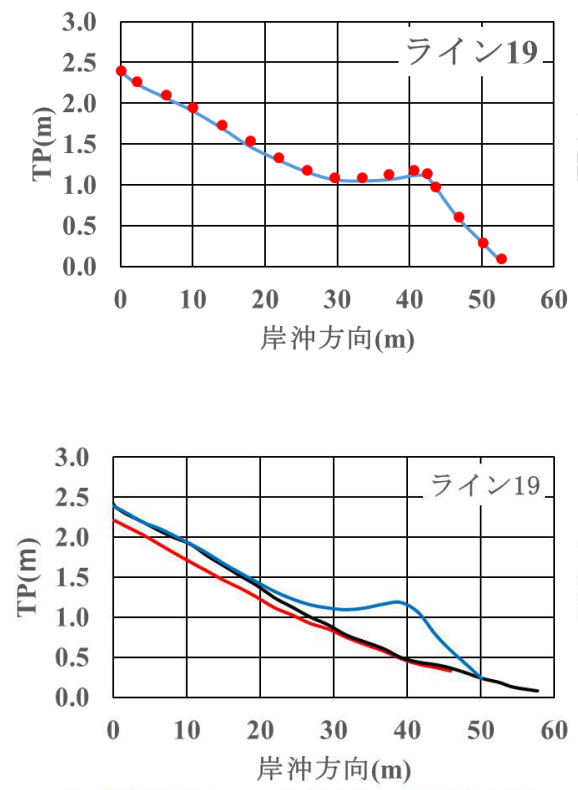

一11月29日 - 12月18日 - 1 月13日

\section{(3) 地盤高変化}

図-9は，等高線 $0.0 \mathrm{~m}$ と $3.0 \mathrm{~m}$ で囲むエリアを抽出し， 地盤高から土量を求めたものである。図-9によると，土 量は11月から12月にかけて52,800 m³ 3 か 49,000 $\mathrm{m}^{3}$ まで減 少し，12月から1月にかけて53,200 $\mathrm{m}^{3}$ に増加している. 11月と1月の土量は，わずか $400 \mathrm{~m}^{3} ， 1$ 月が多い. 汀線は, 11月から1月にかけて全体的に前進しているが，土量の 変化は異なった結果となった。 そのため, 面的な地盤高 の変化を調べるために，DSMによる解析を行った.

図-10は，11月から12月にかけての地盤高の変化を. 図-11は，11月1月にかけての地盤高の変化率をそれぞれ 示したものである. 地盤高の変化は，QGISのラスタ計 算機能を使い，12月のDSMから11月のDSMの減算，1月 のDSMを11月のDSMで除算を行いそれぞれ算出した. ただし，減算および除算は各月の領域が互いに重なり合 う箇所についてのみ行っている.

図-10によると，測線で5から7および測線14，15，測 線25で地盤高の低下がみられ，侵食している傾向が分か

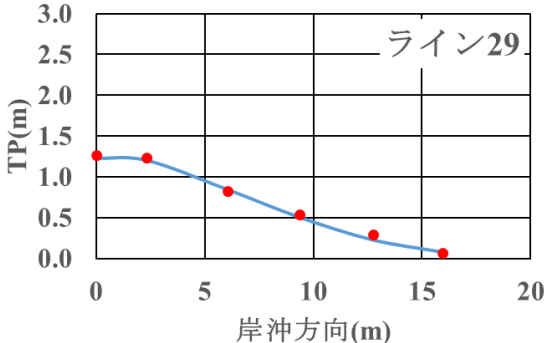

図-6 1月の岸沖方向断面図 (青線 : RTK-GPS，赤点 : モデル)

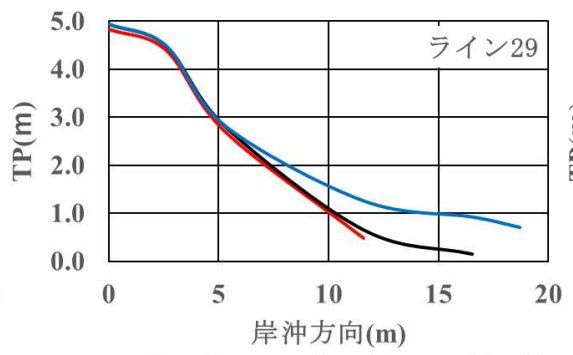

一11月29日 一 12月18日 一1月13日

図-7 断面の経月変化
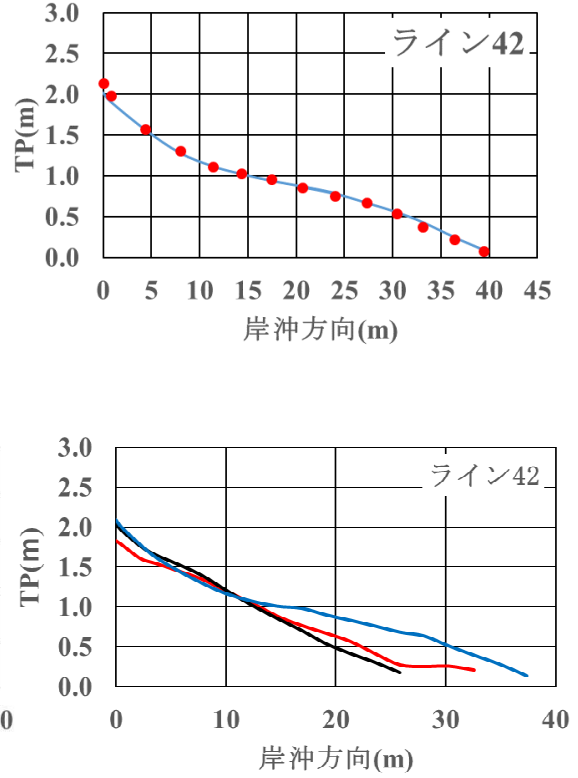

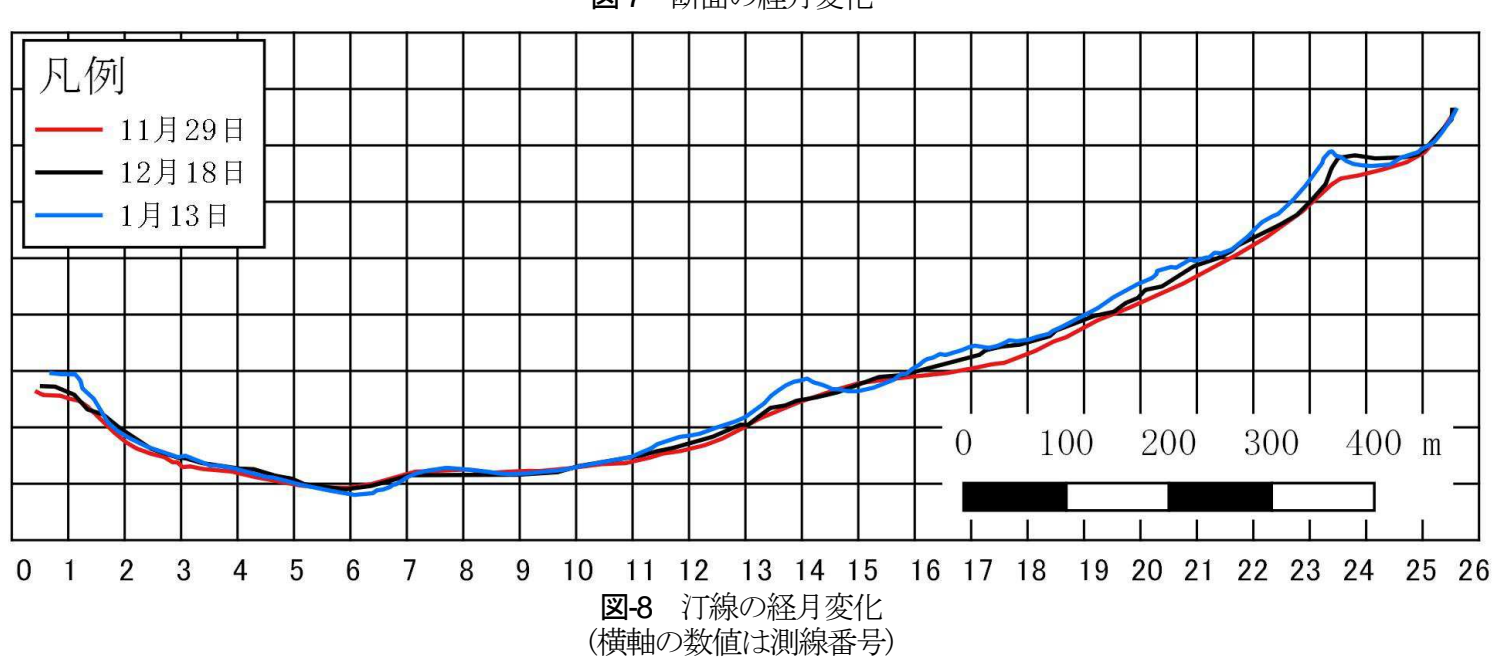


る. 測線8および測線15,測線16間にみられるように，沖 側で地盤高の低下による侵食, 岸側で地盤高の増加によ る堆積などの状況が面的にとらえることができる.

図-11によると，測線1から4，11から14，16から24で 1.5倍程度の地盤高の増加による堆積が認められる。一 方，測線5から8，15，25で地盤高の低下による侵食が認 められる.

3次元モデルを用いた解析は，地盤高の増減だけでは なく増減の割合なども比較的簡単に算出できる.

このように，面的な堆積，侵食傾向の簡易的なモニタ リングが可能であることが分かった.

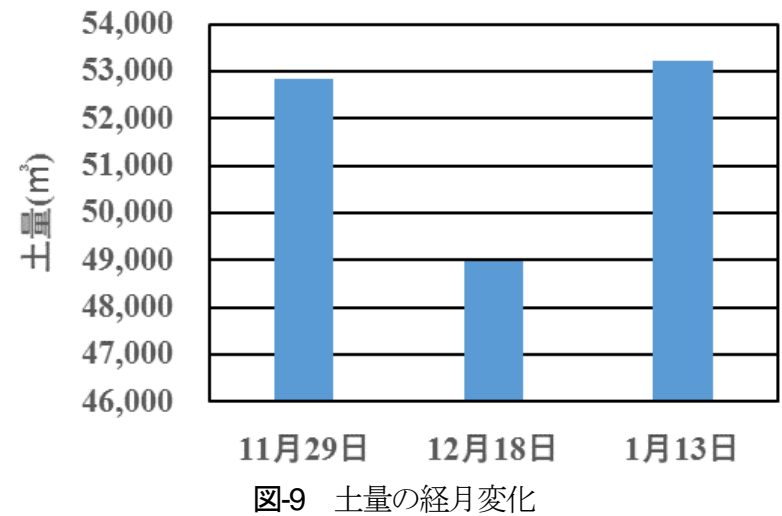

\section{UAVの活用}

RTK-GPSを用いた東西約1.5kmの海岸の調査として, 汀線測量および岸沖方向の断面測量を行うのに掛かる時 間は，3から4時間程度であるが，空中撮影による所要時 間は準備も含め30分程度であり，標定点の測量をあわせ ても2時間程度であり，半分程度の時間で終了すること ができる. なおかつ，面的なデータの取得が可能である。 さらに，高頻度で調査を行う場合は，飛行ルートを記録 させそのルートを活用し次回の飛行が可能であり，同じ ルート上からの空中写真撮影が可能である.

以上のように，メリットが多い反面，落下の危険性が あり，被害を与える可能性があるために，機体のチェッ クや安全性の確認を怠らないことが重要である未未然の 事故防止としては，気象条件や周辺状況の確認，必要な 携帯品の確認，飛行点検をチェックリス卜等も用い，飛 行前のチェックを入念に行う必要がある. チェックリス 卜については，国土交通省九州地方整備局でも行ってお り10)，参考にできる.

なお，安全な飛行に対しては、国土交通省の「無人航 空機（ドローン、ラジコン機等）の安全な飛行のための ガイドライン」2)を遵守する必要がある.

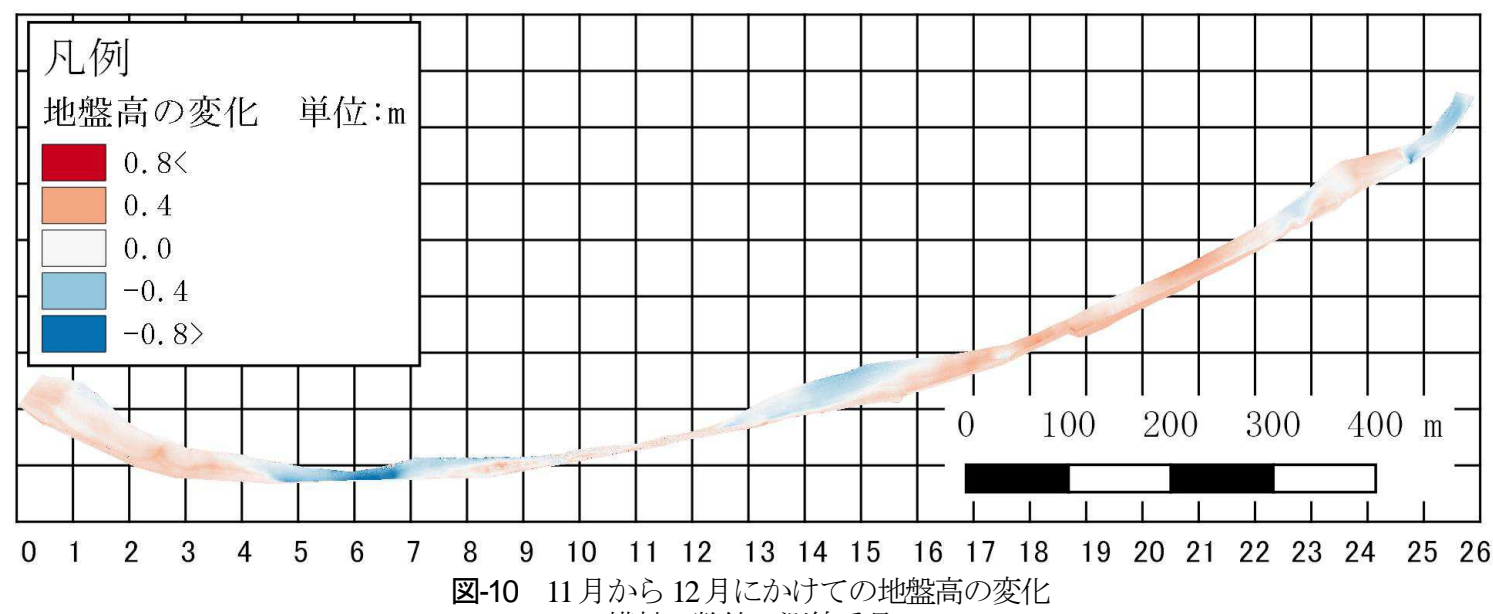
(横軸の数值は測線番号)

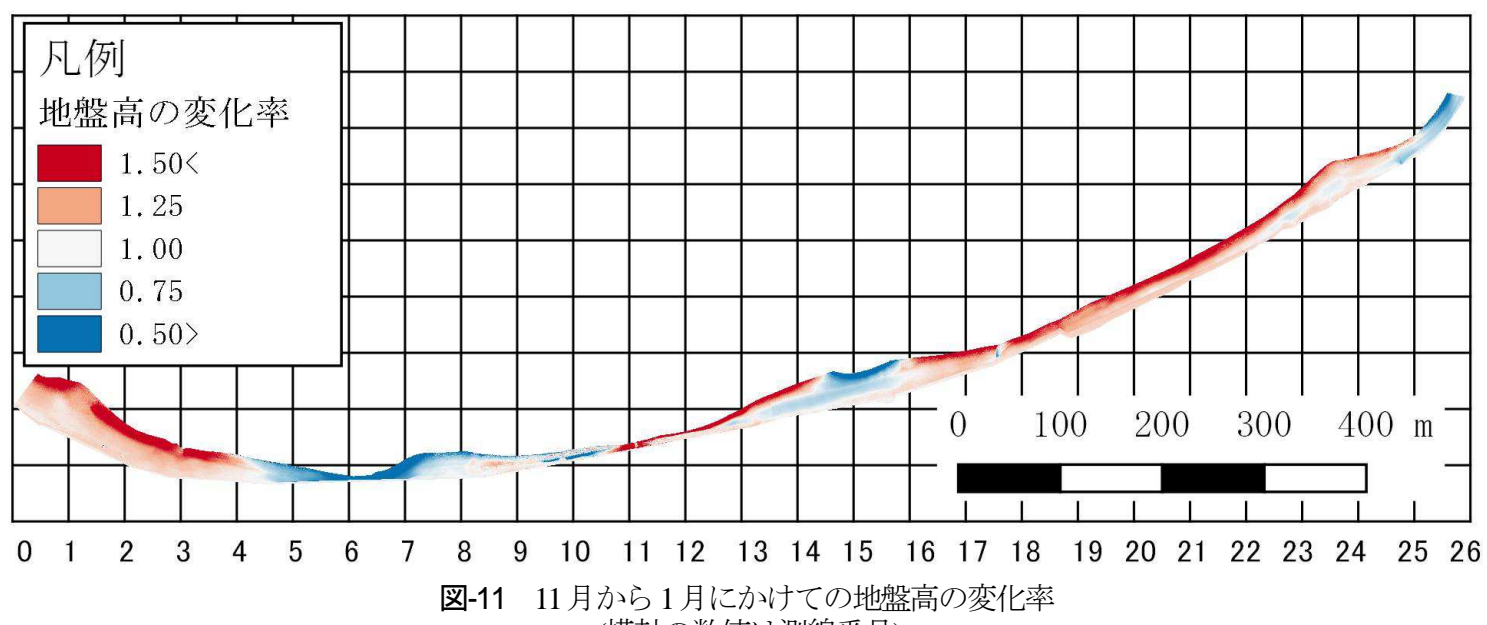

(横軸の数值は測線番号) 


\section{7 おわりに}

本研究では，砂浜域を比較的高頻度で，なおかつ簡易 的にモニタリングできるシステムを開発することを目的 としている. 本報では，UAVによる空中写真から 3 次 元モデルを作成し海岸地形変化の解析を行い，以下のこ とがわかった。

(1)UAVは東西約 $1.5 \mathrm{~km}$ の海岸を10分程度の飛行で空中写 真を取得できた。

(2)UAVによる空中写真から得られたRMSE值(平均二乗 誤差)は，標定点で水平精度 $0.021 \mathrm{~m}$ ，高さ精度 $0.018 \mathrm{~m}$ で あった，検証点では，水平精度 $0.053 \mathrm{~m}$ ，高さ精度 0.029mであった。

(3) UAVによる手法は効果的で，面的に地形情報を取得 することができ，任意の断面形状を捉えることができ る.

（4）面的な堆積，侵食傾向の簡易的なモニタリングが可 能であるこが分かった。

UAV用いた調査では，記録された飛行ルートを活用 することで効率的で，簡易的なモニタリングを可能にす るこができた.

謝辞 : 本研究を進めるにあたり，調査の協力をいただ いた鳥取大学海岸研究室の皆さま，3次元モデルの作成 を行ってもらった日本ミクニヤ(株)の大塚真司氏に深く感 謝いたします。本研究は，日本学術振興会より助成を受 けた「基盤研究（C）」の研究成果の一部であることを 付記する.

\section{参考文献}

1) 市村 康・福岡和明・黒岩正光・竹本勇介(2015)：マルチ コプターを用いた沿岸域調査に関する研究，日本沿岸域 学会研究討論会 2015 講演概要集, No.28, CD-ROM.

2) 国土交通省(2015): 無人航空機（ドローン、ラジコン機等） の安全な飛行のためのガイドライン， http://www.mlit.go.jp/common/001110370.pdf.

3) ミニサーベイヤーコンソーシアムネクスト(2015) : マルチ ローターヘリコプター安全ガイドライン,第 2.1 版, http://mini-surveyor.com/information.html.

4) 日本写真測量学会(2015) : 測量調査に供する小型無人航空 機を安全に運航するための手引き, http://www.jsprs.jp/.

5) 国土交通省国土地理院(2016) : 公共測量における UAV の 使用に関する安全基準(案),

http://psgsv2.gsi.go.jp/koukyou/public/uav/index.html.

6) 国土交通省国土地理院(2016）：UAV を用いた公共測量マニ ユアル(案),

http://psgsv2.gsi.go.jp/koukyou/public/uav/index.html.

7) 小花和宏之・早川裕式・斉藤 仁・ゴメスクリストファ 一(2014) : UAV-SfM 手法と地上レーザ測量により得られた DSMの比較，写真測量とリモートセンシング 53(2),pp67-74.

8) 早坂寿人 - 大野裕幸・大塚 力 $\cdot$ 関谷洋史・㴰繁幸・中野 一也・小林 浩・鈴木英夫(2015)：UAV による撮影画像を 用いた三次元モデリングソフトウェアの精度検証，日本 写真測量学会平成 27 年度年次学術講演会発表論文集, pp1-4.

9) 井上 公・内山庄一郎・鈴木比奈子(2014)：自然災害調査 研究のためのマルチコプター空撮技術，防災科学研究所 研究報告，第 81 号, pp61-98.

10) 坂井佑介,杉町英明(2015) : 災害現場調査におけるマルチコ プターの活用報告，土木技術資料，No.4，Vo;.57，pp.28-31.

(2016.2.4受付)

\section{STUDY ON COASTAL TOPOGRAPHIC CHANGE ANALYS UTILIZING UAV}

\section{Masamitsu KUROIWA, Ryouta SUEYOSHI, Yasushi ICHIMURA and Kazuaki FUKUOKA}

The purpose of this study is to develop the system that the topography of sandy beach can be observed using UAV(Unmanned Aerial Vehicle), as the one of the method for considering the countermeasures aginst the coastal erosion probrem in Uradome Beach, Tottori. In this paper, the coastal topographic change in the Uradome beach was analyzed from the three-dimensional model using SfM (Structure from Motion) associated with the aerial image obtained by the UAV, and the accuracy of the analyzed result was discussed. The UAV used in this study was four wings flight vehicle, and the areal photos were taken per two seconds with a height of T.P.80 meters. The photos of approximately 200 sheets were analyzed by using SfM and GIS software. The observation using UAV along the coastline worked out in 20 minutes about 2 kilometers. The accuracy of the observation with RMSE was verified from a result of the comparison between the RTK-GPS and the UAV survey, the RMSE was about $0.05 \mathrm{~m}$. 